\title{
Mutual Vulnerability: Case U.S. - Colombia - Mexico - Ecuador
}

\author{
Vargas Borbua Robert*², Bangeppagari Manjunatha ${ }^{1}$, Darwin Rueda Ortiz ${ }^{1}$, \\ Mariadoss Selvanayagam ${ }^{2}$, Rowe $\mathrm{Wendy}^{3}$ \\ ${ }^{1}$ Universidad de las Fuerzas Armadas ESPE, Sangolquí- P.O.BOX: 171-5-231B, Ecuador, South America \\ ${ }^{2}$ Loyola - ICAM College of Engineering and Technology (LICET), Loyola campus, Chennai, India \\ ${ }^{3}$ School of Leadership, Royal Roads University, Victoria, Canada
}

\begin{abstract}
This article examines the interdependence of security and mutual vulnerability between countries, regardless of whether they are developed or developing, rich or poor. It analyzes the situation in Colombia after the "Colombia Plan" and Mexico after the "Merida Plan". In addition, it highlights the negative impact on Ecuador after its fight against narcoguerillas in Colombia. Ecuador has become a country of refugees, many of whom are Colombians fleeing the internal conflict, violence and insecurity of their country. Finally, this article highlights that security of the region depends not on overcoming threats in a country, but rather in preventing the causes of insecurity in society.
\end{abstract}

Keywords: Colombia drug war, Human security, Refugees in South America, Ecuador crime, US border drug intervention.

\section{INTRODUCTION}

In March 2008, Colombia, supported by U.S. military, bombarded Angostura, a specific area in Ecuadorian territory, killing guerrilla leaders and combatants, one Ecuadorian citizen and others foreign. This dramatic event resulted in immediate diplomatic and military reaction from Ecuador; the tensions between the two countries triggered a regional response and international concerns across the Americas. Many Latin American countries expressed to be disagree with the violation of Ecuadorian sovereignty by military forces of Colombia. However, others as U.S. supported the action of the government of Colombia. France called to "containment" the diplomatic crisis between Colombia, Ecuador and Venezuela (Reaccion de la OEA en la crisis regional 2008). Colombia expressed their diplomatic apologies to Ecuador and justified the incursion as a mission to destroy mutual enemies: terrorism and narcotraffic. However this was not the end of the matter. This military action by Colombia, derived from an internal conflict and local problem affected regional and international relationships, even arousing worldwide attention.

In this paper, we will analyze the interdependence and mutual vulnerability, between the Global South (primarily the drug producing countries of South America) and the Global North (primarily represented by United States) as a result of the Colombian internal conflict. Further, this paper will examine the interconnectedness between the preservation of life (personal and physical security) and threats of human security such as poverty, hunger, discrimination, uncertainty and violence. In this context, we would like to elucidate first the internal conflict in Colombia and the results of military and economic U.S. aid to Colombia (Plan Colombia), secondly the movement of the violence and drug cartels from Colombia to Ecuador and Mexico; and finally, the implications of regional violence on refugees and displaced people, especially children and women. This conflict resulted inhuman and economic insecurity ripple effects over neighboring states and region, which in turn affected the United States.

\section{INTERNAL CONFLICT IN COLOMBIA}

Colombia has been entangled with an internal conflict for more than 50 years. In 1960s the Revolutionary Armed Forces of Columbia (FARC) and National Liberation Army (ELN) - leftist, communist insurgency-established the armed fight as a path to find social and economic equality and take control of the government (Ibáñez 2008). To fund their activities, all revolutionary groups in Colombia were involved in criminal activities, such as the drug trade (coca base, cocaine, heroin and marijuana), kidnapping for ransom across the country, and illegal gold mining. Many violations of international humanitarian law and human rights were perpetrated, including the seizure and killing of civilians, use of indiscriminate weapons (landmines and gas cylinder bombs), hostage-taking, inhumane treatment of prisoners, recruitment of child soldiers, etc. 
(Human Rights watch 2001; Human Rights Watch 2014). The violence was increased many fold in 1970s due to the drug cartels, which were created as a mechanism to fund the political activism agenda. For example during the period 1970 to $2010,39,053$ people were kidnapped, 7400 children were trained in guerrilla warfare, 223 people were killed and 1343 people injured by 95 terrorists attacks (Muller 2015). There are several reasons why these illegal groups were strong enough to challenge the legal government. Primarily was the fact that there was a lack of strong government state presence in many Colombian counties and the insurgency groups stepped in to provide social services and entertainment to the population (FARC's radio station, TV, and Internet), as example in 1990s the FARC's 20,000 people controlled nearly 50\% of Colombian territory (Peceny and Durnan 2006), including the demilitarized zone. Secondly, the legal government also failed to respond to the issues of safety and security for its people. Local people often turned to FARC to protection. According to Berti (2015), it is a practice in other armed organizations such as Hezbollah, Hamas, or Taliban (Berti 2015), which built strong bonds with the population. Additionally the unequal human development conditions in Colombia segregated society between the periphery and the central cities, so FARC and others have only managed to sustain themselves in rural areas where the state has been largely absent, acting as a substitute for the state (Suelt 2006), generated populace resentment, incidences of violence, criminal attacks, and illegal trades, which have spread out to the neighboring states in South and Central America. However, this has spread to the U.S. with the expansion of drugs trade and the formation of violent gangs. Therefore this type of international, criminal organizations could not be eliminated by Colombia without the massive support of the United States.

\section{U.S. INVOLVEMENT IN COLOMBIA DRUG WAR}

The U.S. had supported the Colombian government to fight against the communist guerrillas since the 1960s. But in 1999 "the Plan Colombia" was implemented to provide Colombia with additional military and civilian personnel as well as other economic resources so as to combat and defeat illegal armed groups. Colombian Army increased the number of professional soldiers by $290 \%$, and the weapons, technology and the equipment correspondently (Muller 2015). Then, in the secure zone the rest of the government system created the social and economic security that sought to draw people away from the criminality and improve human development conditions (Marks 2007). From the perspective of the U.S. and Colombian governments, this investment paid off, because more than $30 \%$ of the territory came under government control, and resulted in a significant reduction in coca plantations, threats of kidnapping and terrorist acts, decreased homicides, and less casualties on soldiers and police (Boot and Bennet 2009). However, the aerial eradication of these activities caused significant collateral damage, resulting in the destruction of all types of crops, increased pollution of soil and waterways, increased risk of extinction for Colombian [and neighbors] fauna and flora, and increased health effects. Many residents of spray zones have had a variety of skin, respiratory, and other ailments (Isacson 2002). Subsequently, the peasants and farmers were displaced and forced to migrate to new places for their Agriculture and livelihood. The coca cultivation extended into forest areas and national parks; as a result there was intense deforestation, within Colombia and Peru, Venezuela, Brazil, and Ecuador.

The unified effort taken by the US and Colombia to suppress the communist guerrillas resulted in many problems to the neighboring countries and the region at large. However as the drug trade in Colombia declined, displacement effects emerged. The market price of cocaine rose significantly, and commercialization spread to Ecuador, Mexico and other countries in Central America (Derks-Normandin 2014). The past street violence, illegal weapons trade, gangs and criminal organization battles resulted in many deaths of civilians, high insecurity perception, and as a result there was flow of refugees and displaced people from Colombia to Ecuador, Mexico, and other parts of the South American region and the world.

\section{DISPLACEMENT OF DRUG TRADE AND VIOLENCE TO MEXICO}

The relative success of Plan Colombia limited the actions of drug cartels in Colombia, but amplified these in Mexico. Indeed, Mexico showed a dramatic increase in the violence and crime rates which was estimated to be more than 1'000,000 deaths by 2013 (Booth 2012). The Mexican Drugs Cartels (MDC) have been controlled the illicit drug market entering the U.S. which generated around $\$ 40$ billion in 2009 (Cook 2007), despite the U.S. stricter border control measures imposed after September 11, 2001. The control of territory and trafficking routes triggered a wave of battles between rival criminal organizations and increased significant extortion, kidnappings, robberies, and murders. This violence impacted the Mexican society in issues such as government corruption, violations of human rights, degradation of public health, compromise of journalists and the media, murders of politicians and law enforcement persons massacres and exploitation of migrants, human trafficking, etc. The Colombia cartels basically shifted their illegal activities to other countries by outsourcing drug trafficking to the Mexican gangs. 


\section{U.S. GANGS AS BUTCHERS FOR THE MEXICAN CARTELS}

U.S. based gangs formed, acting as butchers for Mexican drug cartels in most major U.S. cities (National Gang Intelligence Center 2011). A spike in killings, kidnappings and home invasions increased along the U.S. Southwest border region. The U.S. based gangs established wide-reaching drug networks with Central American and Mexican drugs cartels to assist in the smuggling of drugs, weapons, illegal immigrants along the Southwest Border (National Gang Intelligence Center 2011). In December 2008, the U.S. Joint Forces Command stated that it was concerned that the Mexico internal drug war would have a major impact on the stability of the Mexican State, and therefore it would demand American involvement so as to safeguard US homeland security U.S. has increasingly allocated resources and money to combat smuggling of illegal drugs, money, and weapons from Mexico. Further National Guard troops have been deployed along the U.S. border with Mexico to assist with border protection and enforcement activities, as well as to help in training additional Customs and Border Protection agents (Dwyer 2010).

\section{UNDERLYING POVERTY AND SECURITY ISSUES IN SOUTH AMERICA}

There are similarities between Mexican and Colombia: the failure of government to provide opportunities to improve human development issues and provide security thus increasing conditions of poverty, as happened in Colombia. The armed insurgency groups are looking for political power, either by overthrowing the existing regime (Colombia), or, as in Mexico, to paralyze and remove the government as a threat to their operations (Farwell and Arakelian 2014). Since 2006, the Mexican government has employed the Mexican Armed Forces to combat the drugs and drug trafficking and to create a secure zone that allows government institutions to implement human development and security (Ribando-Seelke and Finklea 2015). Finally since 2008, Mexico and Central America have received U.S. collaboration through "Merida initiative"- resources for law enforcement training and equipment and technical advice to strengthen the national justice system (Ribando-Seelke and Finklea 2015).

If the Mexican government defeats the drug cartels and implements minimum conditions imbed the criminal activities, the drug cartels would have to find other places where they can operate. They will choose a country in the "Global South ", an undeveloped or developing country where security levels are low. Could it be Central or South America, or Africa, or a South Pacific country? The circle of insecurity will start again in another poor country and end in U.S. and Canada-, countries in the "Global North" which create the demand for illegal drugs and have economical investment in weapons development and supply. While disparities between north and south exist, the mutual vulnerability of both worlds will continue. The countries which are affected by illegal drugs should revisit the anti-drugs programs from a public health perspective and not just as security problem.

\section{A REFUGEE CRISIS IN LATIN AMERICA}

According to former Brazilian President Fernando Henrique Cardoso (De Cordova 2009), the violence caused by unequal human development conditions and minimum human security is driving Latin America into a downward spiral of poverty, lack of welfare, and violence (De Cordova 2009). The violence in Colombia has resulted in the worst humanitarian crisis in the Western Hemisphere; almost two million Colombians have become internally displaced or have left their country as refugees (Human Rights watch 2001). In the last twelve years more than 200,000 Colombian refugees migrated to Ecuador. This developing country has "the most liberal asylum policy" (Poe and Isacson 2009), but does not have enough financial resources to resettle all these refugees due to their own poverty and internal problems; they need more funds from international agencies. Therefore responding to the refugee crisis is a huge challenge for the Ecuadorian government. Many indigenous and Afro-Caribbean Colombian refugees don't have any identification which limits them to humanitarian assistance. They cannot obtain work permits or access services such education. $40 \%$ of secondary school age youth were not enrolled in school in 2011(FLACSO 2011). These youth (and adults) are not only at risk of being exploited, discriminated, abused, but may turn into crime, gangs, prostitution or trafficking to survive (White 2011). The circle of insecurity opened in Colombia has raised the vulnerability of average citizens, not only in Colombia but also in Ecuador and other countries. Even though the Colombian refugees have escaped the war, criminal attacks, torture, and violence of their own country, they continue to face poverty, hunger, lack of health care and protection from diseases, and lack of a decent job. This has deprived them of the possibility of living in a traditional culture with political rights.

\section{CRIME AND VIOLENCE AMPLIFIED IN ECUADOR}

Meanwhile the crime rates and violence have been amplified in Ecuador. Some authors consider the increase of general violence is due to Colombian migrants who have been camouflaging within the local communities and involved in criminals and illegal economic activities such as money laundering, sex trafficking, and migrant exploitation (Jarrín 2004). Others argue that the incursions by Colombian guerrillas, 
paramilitaries, drug traffickers and even the Colombian army in Ecuadorian territory have also promoted increased the violence in the zone (Moreano 2005). More than 4,000 Ecuadorians, including 500 persons belonging to the Shuar and Kichwa indigenous communities, abandoned their land in the area of Rio San Miguel due to the fear of losing their lives, their families or their communities (Centro de Documentaciónen Derechos Humanos "Segundo Montes Mozo SJ" 2001). The fear of violence has also forced them to flee their homes without any security considerations such as hunger or diseases, which at the end killed manymore people than through the direct impact of the war (University of British Columbia 2005).

\section{ADDITIONAL SECURITY ISSUES IN ECUADOR}

In order to protect the frontiers from external incursions and to protect the border population in rural areas the Ecuador's government answer is primarily based on national security. Indeed, after 1999, when Ecuador and Peru signed the peace agreement, the Ecuadorian army shifted its focus to solving threats such as terrorism (guerrilla), narcotraffic, and migration in the northern border (Gallardo 2005; Jarrín 2004). These security actions also generated stress not only in the border zone but also in main cities, where $60 \%$ of refugees have settled. Colombia's problems have created an internal migration problem in Ecuador, and this has caused further vulnerability in Ecuador. Recently aggravated by the presence of the Sinaloa cartel. It is promoting micro trafficking and violence through the gangs. The Ecuadorian problems are sort of a mirror of the violence experienced in Colombia and now in Mexico.

\section{CONCLUSION}

Vulnerability and security of a country or region depends largely on the ability of the society (s) to prevent the causes of insecurity to their population. In addressing these risks, as it was pointed out in the cases above, the risks have shifted regionally to other countries that are similarly vulnerable. In combating these risks there must be a regional review of the poverty and underdevelopment issues so as to come up with a viable solution to the bigger problem of human security.

While the violence, in general, and drug trade, in particular, hurts the citizens of all countries, it is likely the poorest countries suffer the most because their citizens have relatively fewer opportunities to engage in conventional labor with dignity. In all the countries, the poor suffer the most from the drug trade-they are the most vulnerable for exploitation of cartels, they are arrested and ill-treated more so than the rich people, and they tend to live in communities where drugs are relatively common. Their health deteriorates day by day and they suffer effects from criminal activity (drugs, contraband, war, etc.). In developed and rich countries, the crime control agencies are better funded to reduce the criminal influence on a population. Mutual vulnerability therefore depends largely on the ability of society to eliminate human security risks and, if they cannot achieve that alone, they must work to gain the assistance of the rich societies with more power in the world.

We conclude that there must be a concerted effort to address the mutual vulnerability of the north (U.S) and south (South America). They must combine their resources with a regional strategy to mitigate the risks that is taking advantage of their vulnerability. Also they should examine together the policies that can help to mitigate the regional risks. The security of the system depends on the weakest link. Global understanding of the security issues and global cooperation in addressing these issues is needed to achieve global security.

A region or community will not be safe, if another region or community does not overcome the main threats of insecurity. The interconnectedness of the system can make this mutually reinforcing or mutual vulnerable. Vulnerability and security depends largely on the ability of societies to prevent the causes of insecurity to their population.

\section{REFERENCES}

[1] Berti B. The surprising way groups like ISIS stay in power. Retrieved from TED talks: 2015. https://www.ted.com/talks/benedetta_berti_the_surprising_way_groups_like_isis_stay_in_power/transcri pt?language $=$ en.

[2] Boot M, Bennet R. The magazine: The Colombian miracle. 2009. Retrieved from The Weekly Standard: http://www.weeklystandard.com/Content/Public/Articles/000/000/017/301nyrut.asp.

[3] Booth W. Mexico's crime wave has left about 25,000 missing, government documents show. The Washington Post, 2012, p. 2.

[4] Centro de Documentación en Derechos Humanos "Segundo Montes Mozo SJ". (2001). Los derechos humanos en la frontera colombo ecuatoriana. Cronología de la crisis humanitaria y la militarización de Quito.

[5] Cook C. Mexico's drugs cartels. Congressional Research Service. 2007. Retrived from http://www.fas.org/sgp/crs/row/RL34215.pdf. 
[6] De Cordova J. Latin American panel calls U.S. drug war a failure. The Wall Street Journal, 2009, p. 2.

[7] Derks-Normandin M. Building Peace in the Midst of Conflict: Improving Security and Finding Durable Solutions to Displacement in Colombia. Washington, DC: Brookings Institution. 2014.

[8] Dwyer D. Obama Authorizes Deployment of More National Guard Troops Along Border. abcnews, 2010, p. 2. Retrieved from http://abcnews.go.com/Politics/obama-authorizes-deployment-national-guardsouthwest/story?id=10740858.

[9] Farwell J, Arakelian D. Not a mere crime problem. StrategicStudies, Spring 2014, 40 -54.

[10] FLACSO. Refugiados urbanos en el Ecuador. Estudios sobre los procesos de insercion urbana de la poblacion colombiana refugiada, el caso de Quito y Guayaquil. 2011. Retrievedfrom ACNUR: http://www.acnur.org/biblioteca/pdf/7530.pdf?view=1.

[11] Gallardo J. (2005). El Plan Colombia y sus efectos sobre el Ecuador.Quito: Eskeletra.

[12] Human Rights watch. Beyond negotiation: International humanitarian law and its application to the conduct of the FARC-EP. New York: Human Rights Watch. (2001). Retrieved from https://www.hrw.org/report/2001/08/01/beyond-negotiation/international-humanitarian-law-and-itsapplication-conduct-farc.

[13] Human Rights Watch. Colombia: FARC battering Afro-Colombianareas. Human Rights Watch. (2014). http://www.hrw.org/news/2014/07/30/colombia-farc-battering-afro-colombian-areas.

[14] Ibáñez A. Civil conflict and forced migrations: The microdeterminants and welfare losses of displacement in Colombia. World Development, (2008). 36(4), 659-676. doi:10.1016/j.worldev.2007.04.013.

[15] Isacson A. Colombia's human security crisis. Human security in Latin America, 2002, 2. 25-40. Retrieved from http://www.peacepalacelibrary.nl/ebooks/files/UNIDIR_pdf-art1446.pdf.

[16] Jarrin O. La Junta de Seguridad Ciudadana: el caso de. Revista Nueva Sociedad, 2004. 147 -156.

[17] Marks T. A model counterinsurgency: Uribe's Colombia (2002 - 2006) vs FARC. Military Review, 2007, 41 - 56. http://www.au.af.mil/au/awc/awcgate/milreview/marks2.pdf.

[18] Moreano E. (2005). Evaluación de la política de seguridad de la frontera norte de Ecuador. In J. Ponce (Ed.), La seguridad del Ecuador: del 11 de Septiembre al Plan Patriota, 2005, pp. 171 -190. Quito: FLACSO.

[19] Muller G. How military actions affected citizen security during Plan Colombia. Monterey, CA: Naval Postgradute School. (2015).

[20] National Gang Intelligence Center. Reports and publications: 2011 National gang threat assessment Emerging Trends. 2011. Retrieved from The FBI Federal Bureau of investigation: https://www.fbi.gov/stats-services/publications/2011-national-gang-threat-assessment/.

[21] Peceny M, Durnan M. The FARC's best friend: U.S. antidrug policies and the deepening of Colombia's civil war in the 1990s. Latin American Politics and Society, 2006, 48(2), 95 -116. doi:10.1111/j.15482456.2006.tb00348.x.

[22] Poe A, Isacson I. Research: Ecuador's humanitarian emergency. 2009. Retrieved from Center for international policy: http://www.ciponline.org/research/entry/ecuadors-humanitarian-emergency.

[23] Reacción de la OEA en la crisis regional. (24 de marzo de 2008). El Clarin, pág. 1.

[24] Ribando-Seelke C, Finklea K. U.S.- Mexican security cooperation: The Mérida initiative and Beyond. Washington DC: Congressional Research Service. 2015. Retrieved from https://www.fas.org/sgp/crs/row/R41349.pdf.

[25] Suelt Cock V. The Relation between Human Security and Peace in Colombia .Human Security Perspectives, 2006, 1 (3), $16 \quad-\quad 21$. Retrieved fromhttp://www.etcgraz.at/typo3/fileadmin/user_upload/ETC-Hauptseite/human_security/hs-perspectives/pdffiles/V1I3/04_VanessaSuelt.pdf.

[26] University of British Columbia. (2005). Human Security Report 2005: War and peace in the 21st Century. London: Oxford University Press.

[27] White A. In the shoes of refugees: providing protection and solutions for displaced. 2011. Retrieved from UNHCR: Retrieved from http://www.unhcr.org/4e4bd6c19.html. 